\title{
Home-Based Working During Covid-19 Pandemic: Experience of Turkish Software Professionals
}

\author{
Gül TOKDEMIR ${ }^{1}$ \\ ${ }^{1}$ Çankaya Üniversitesi, Bilgisayar Mühendisliği Bölümü, Ankara \\ Corresponding Author e-mail: gtokdemir@cankaya.edu.tr ORCID ID: http://orcid.org/0000-0003-2441-3056 \\ Geliş Tarihi: 01.05.2021 Kabul Tarihi: 29.09.2021
}

\begin{abstract}
Keywords

This study explores the home-based working experience of software professionals during Covid-19

Software professionals; pandemic. Through an online survey, it examines the challenges of home based working in relation to Covid-19 pandemic; Home-based working; Perceived productivity characteristics of such work settings. Furthermore, it investigates the relation between home-based working characteristics and self-reported productivity via bivariate analysis. The results of this study show that it was mostly easy to adopt to the home-based new work setting while most of the software practitioners stated that they worked longer hours during the pandemic period. Housework and kids were reported as the two primary interruptions in home based setting. Additionally, afternoons and mornings were mentioned as the most productive work intervals for software professionals.
\end{abstract}

\section{Covid-19 Salgını Sırasında Evden Çalışma: Türk Yazılım Profesyonellerinin Deneyimleri}

\author{
Anahtar kelimeler \\ Yazılım uzmanları; \\ Covid-19 pandemisi; \\ Evden çalışma; \\ Algılanan verimlilik
}

\begin{abstract}
Öz
Bu çalışma, Covid-19 salgını sırasında yazııım profesyonellerinin evden çalışma deneyimlerini araştırmaktadır. Bir anket aracılığıyla, bu tür çalışma ortamlarının özellikleriyle ilişkili olarak evden çalışmanın zorlukları incelenmiştir. Ayrıca, iki değişkenli analiz yoluyla, ev tabanlı çalışma özellikleri ile üretkenlik arasındaki ilişki araştırılmıştır. Bu çalışmanın sonuçları, yazılım profesyonellerinin pandemi döneminde daha uzun saatler çalıştıklarını ve evden çalışma ortamına adapte olmanın çoğunlukla kolay olduğunu göstermektedir. Evden çalışma ortamlarında ev işleri ve çocukların en önemli kesinti nedeni olduğu bildirilmiştir. Ayrıca yazılım profesyonelleri için öğleden sonraları ve sabahların en verimli çalışma aralıkları olduğu belirtilmiştir.
\end{abstract}

(C) Afyon Kocatepe Üniversitesi

\section{Introduction}

Software development process requires concentration and independent working for long hours (Meyer et al. 2019). Accordingly, interruptions in work environments during these extended working periods may occur, which result in nonproductive outputs such as increase in anxiety, error rate and decrease in performance.(Mark et al. 2008, Parnin and Rugaber 2011, Bailey et al. 2000). Especially, distractions as short interval interruptions result in negative mental states associated with annoyance, anxiety, frustration, and hence bring augmented levels of possible errors, stress, pressure related to cost and time (Adamczyk and Bailey 2004, Cutrell et al. 2000, Mark et al. 2008).

In general, interruption disturb the flow of the activities, and the status of concentration whilst performing a software development task, which negatively affects productivity in parallel (Meyer et al. 2017). Besides interruptions, work environment factors also affect the level of performance; in relevant literature, it is acknowledged that factors such as layout, distance between offices, privacy level, control of heating, lighting, ventilation, and noise, workspace density, architecture, and light do 
have a role in manifested volatility of performance (Leaman and Bordass 1999, Oldham 1988). From a similar point of view, and regarding the software development process, DeMarco and Lister revealed that there is a correlation between work environment factors and software developer performance (DeMarco and Lister 1985).

Focusing on recent times, primarily on Covid-19 pandemic, as many knowledge workers in diverse sectors, software professionals started working from home, sharing the same environment with other family members during working days. As expected, this experience posed new challenges in software professionals' daily work activities.

In this sense, this study aims to explore the characteristics of home-based work setting of software professionals during Covid-19 pandemic and furthermore intends to bring a widened perspective on software professionals' home-based working and self-reported productivity during this pandemic.

In this respect, the study elaborates on previous studies, and through a survey, provides valuable insights to management of the software companies and software professionals in reducing the undesirable effects of crisis situations on software professionals' work performance by the analysis of its outcomes.

\section{Background}

The nature of software development process requires long hours of concentration (Meyer et al. 2019). In this respect, work environments/settings, planning of working hours, allocation of resources, team working dynamics, co-worker relationships, interruptions/distractions are all crucial factors for software professionals. These factors influence performance of software professionals and affect levels of productivity in their work tasks.

Recently, due to Covid-19 pandemic and the changing nature of work settings, the importance of these factors have been highlighted more often and attracted more attention from relevant literature as strict measures taken for Covid-19 pandemic forced software professionals to start working from home, i.e. remote work or telework, sharing the same environment with other members of the family, partners, etc. during working hours. As expected, this situation posed new challenges in software professionals' daily work activities.

Working away from regular office place, from anywhere, is termed as remote work or telework. In remote work, employees may work from any location as long as they have a persistent internet connectivity. This way of working has several advantages for professionals, besides its challenges.

For example, telework is found to reduce stress and hence improve positive work outcomes (Conradie and de Klerk 2019). Golden and Veiga mentioned in their study that working from home may result in improved productivity as employees face less distraction caused by co-workers (Golden and Veiga 2008).

On the other hand, it is acknowledged that this way of working has a tendency to increase stress levels of professionals as they try to keep in place the boundaries already settled previously between work and family responsibilities, though disappearing in these new work settings (Hill et al. 1998). As working hours are not clearly defined in telework settings, work and private life domains may overlap resulting in challenges (Raghuram and Wiesenfeld 2004), accordingly reducing limited resources of the individuals, cycle wise resulting in adverse outcomes such as stress, anxiety or burnout. Thus, telework/remote working arrangements is considered as a challenge in managing time, and separating work and private life (IOSH, 2014)(IOSH, 2014)(IOSH, 2014)(IOSH, 2014) and professional duties (Nakrošienè et al. 2019) during daytime. In addition, it may cause frequent interruptions and working longer hours (Johnson et al. 2007).

And consequently, telework or remote work, especially in the case of home based working during Covid-19 pandemic, increased the number of interruptions for software professionals, a situation which is to be considered as a negative effect for workers as interruptions in work environment may result in less productive outputs such as increase in 
anxiety, error rate and decrease in performance (Mark et al. 2008, Parnin and Rugaber 2011, Bailey et al. 2000).

In general, information workers of both small and large scale organizations have to implement multitasking, work in multiple teams and projects (González and Mark 2004) which may cause several interruptions during the daily work activities. This may result in the probability of making mistakes in a task performed that causes repeating the task or totally skipping it (Brumby et al. 2013, Li et al. 2008) and affect stress and productivity of knowledge workers (Czerwinski et al. 2004, Mark et al. 2016). The interruption that occurs at an unexpected point during the execution of a task may cause negative effects (Iqbal et al. 2005) usually reducing attention paid for the task at hand (Kushlev et al. 2016). Reduction in productivity because of interruptions such as unavoidable task switching is shown by a field study, which may be caused by depletion of cognitive resources, the redundancy of work in returning back to the task (Mark et al. 2015).

Factors related to work environment may also affect the level of performance in daily work activities. In related studies, it is acknowledged that layout, distance between offices, privacy level, control of heating, lighting, ventilation, and noise, workspace density, architecture, and light do have a role in manifested volatility of performance (Leaman and Bordass 1999, Oldham 1988).

Regarding productivity, software engineering research showed remarkable interest in how to improve levels of productivity; contributing factors and their effects in software processes (Palvalin 2017, Wagner and Murphy-Hill 2019). In general, not specific to Covid-19 pandemic, productivity is perceived as a concept that is difficult to express by both researchers and experts (Sadowski et al. 2019) for software development. In software development process though, it is a key issue ensuring that resources are utilized effectively and efficiently for the desired software product.

Previous research explored factors effecting productivity of software professionals where several drivers of productivity are listed for knowledge workers such as physical environment, virtual environment, social environment and individual work practices (Palvalin 2017) and specifically for software professionals as well (Wagner and Murphy-Hill 2019). One of the factors is identified as uninterrupted time for the task (DeMarco and Lister 2013). In their comparative study, Parnin and Rugaber mentioned that resuming tasks after interruption is a serious problem for software workers (Parnin and Rugaber 2011). The physical work environment is another important factor affecting productivity of software professionals (DeMarco and Lister 1985).

As software development includes high level of complex activities demanding high concentration, improving physical work environments is expected to enhance productivity. In their multiple step research at Microsoft, Johnson et al. (2019) found that having a work environment free from interruptions is an important factor for productivity.

In the recent years, companies expect software workers to dedicate longer working hours, handle heavier workloads, and work overtime (Meyer et al. 2017). Usually, software professionals work at uneven hours. Non-stop work schedule for a duration of two hours, without any break, causes performance to reduce abruptly (Rodriguez et al. 2018). Performance of the developers' peeks in the evening (before midnight) and then drops after the day changes. Developers may feel to possess more resources to complete a task energetically in specific times of the day. Some developers feel more dynamic in the early morning while others in normal working periods (Tsunoda et al. 2006). Productivity degrades in the early morning and subsequent long working periods (Harrington 2001).

Within the boundaries of the key components for productivity as mentioned above, we studied pandemic forced home-based working characteristics and self-reported productivity of software professionals. In that respect we explored the home-based working factors (i.e. easy adaptation to home-based working, giving enough breaks, being disturbed during the home-based working, technical infrastructure issues, working more compared to past and having interruptions in 
the home-based working environment), preferred working times, interruptions and perceived productivity for the software professionals during Covid-19 pandemic.

\section{Method}

\subsection{Participants}

A total of 321 participants were enrolled in the study. All participants were software professionals working at different companies in Turkey. Within our method of analysis, the exclusion criteria were: (1) full-time home-based workers (2) repeated responses from the same participant (3) non-homebased workers.

\subsection{Research procedure}

A qualitative research design was used for this study. A survey was sent to participants via social networking channels in order to gather their perception about productivity, work pressure and home-based working arrangement. Ethical committee report was obtained from Çankaya University Science and Engineering Sciences Scientific Research and Publication Ethics Committee that covers informed consent form, and the samples of the data collection tools.

In total, 362 participants completed the survey. 321 valid feedbacks were collected and analyzed through SPSS software. The variables were namely; home-based working factors, namely, easy adaptation to home-based working, giving enough breaks, being disturbed, having infrastructure issues, working more, having interruptions and selfreported productivity. All variables were categorical. To explore the relationships between output and independent variables, bivariate analysis with chi square test was applied and significance was checked ( $p<=.005$ ).

\subsection{Variables}

In the survey, we asked participants questions about home-based working characteristics with 2 level answer "yes" or "no". Answers to the following questions were collected for home-based working experience during pandemic: easy adaptation to home-based working (easyAdaptationtoHome
Work), "It was easy to adopt to home-based working during pandemic"; giving enough breaks (giveEnoughBreaks) "I give enough breaks during home-based working", being disturbed (beingDisturbed) "I am being disturbed during home-based working"; having infrastructure issues (Infrastructurelssues ), "I experience infrastructural problems in home-based working"; working more (workingMore) "I am working more compared to past"; having interruptions (havelnterruptions) "I have to handle interruptions during home-based working". Similarly, for self-reported productivity, we asked: "I am more productive during homebased working period compared to past" with 2 level answer "yes" or "no". Additionally, types of interruptions software professionals experienced (Figure 1) and their productive working time intervals were collected through multi-level questions.

\section{Results}

Among participants, around one third of the participants (69\%) were males and $48 \%$ were single. $63 \%$ did not have any children and only $21 \%$ of all participants were living alone (Table 1 ).

Table 1. Demographics of the participants

\begin{tabular}{|c|c|c|}
\hline Variable (n) & $\mathbf{n}$ & $\%$ \\
\hline \multicolumn{3}{|l|}{ Gender } \\
\hline male & 220 & 68.5 \\
\hline female & 101 & 31.5 \\
\hline \multicolumn{3}{|l|}{ Marital status } \\
\hline single & 155 & 48.3 \\
\hline married & 151 & 47.0 \\
\hline other & 15 & 4.7 \\
\hline \multicolumn{3}{|l|}{ Children } \\
\hline None & 203 & 63.2 \\
\hline at least 1 & 118 & 36.8 \\
\hline \multicolumn{3}{|l|}{ Home living } \\
\hline alone & 68 & 21.2 \\
\hline not alone & 253 & 78.9 \\
\hline
\end{tabular}

Based on survey results, most of the software professionals (85\%) reported to adopt to this new working arrangement easily. $26 \%$ of the respondents experienced problems related to the infrastructure during home-based working. $75 \%$ of the software professionals were being disturbed during their working periods at home and $40 \%$ experienced interruptions during their daily work tasks. While $74 \%$ reported to give enough work 
breaks during their daily tasks, 63\% reported working more compared to their previous usual work settings within office environments (Figure 2).

Regarding productivity concern at homes, results showed that those who adopted to the home-based working setting easily, reported to be more productive.

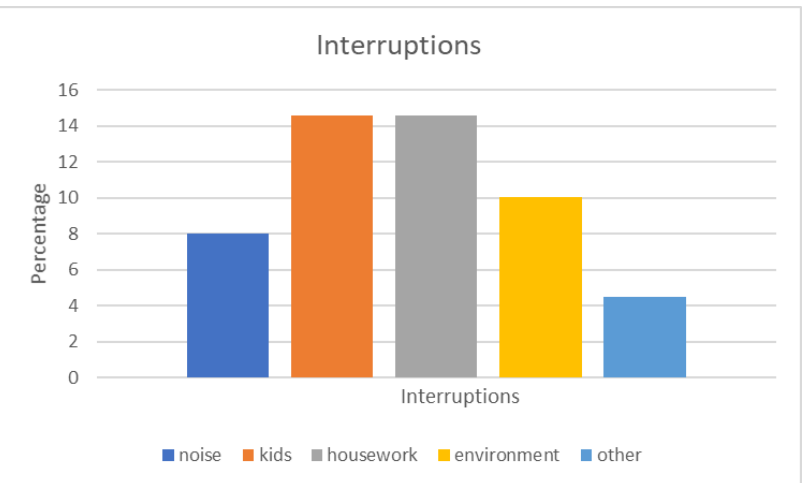

Figure 1. Interruption types during Covid-19 home-based working.

In terms of preferred working time intervals, software professionals reported that their most productive work time is firstly afternoon hours, and morning hours which is followed by mornings (Figure 3 ). On the other hand, in terms of interruptions housework and kids were reported as the two leading interruptions in home based settings (Figure 1 ).

The two-way Chi-square test with two variables resulted in correlation values as given in Table 2 . According to the results of the two-way Chi-square test with two variables, there is a significant relationship between self-reported productivity and variables of easyAdaptationtoHomeWork and $\left(\mathrm{X}^{2}(1\right.$, $\mathrm{N}=321)=39.81, \mathrm{p}<.000)$, giveEnoughBreaks $\left(\mathrm{X}^{2}(1\right.$, $N=321)=38.59, p<.000)$, beingDisturbed $\left(X^{2}(1, N\right.$ $=321)=12.361, p<.000)$, infrastructurelssues $\left(X^{2}\right.$ $(1, N=321)=17.23, p<.000)$, havelnterruptions $\left(X^{2}\right.$ $(1, N=321)=8.52, p<.004)$.

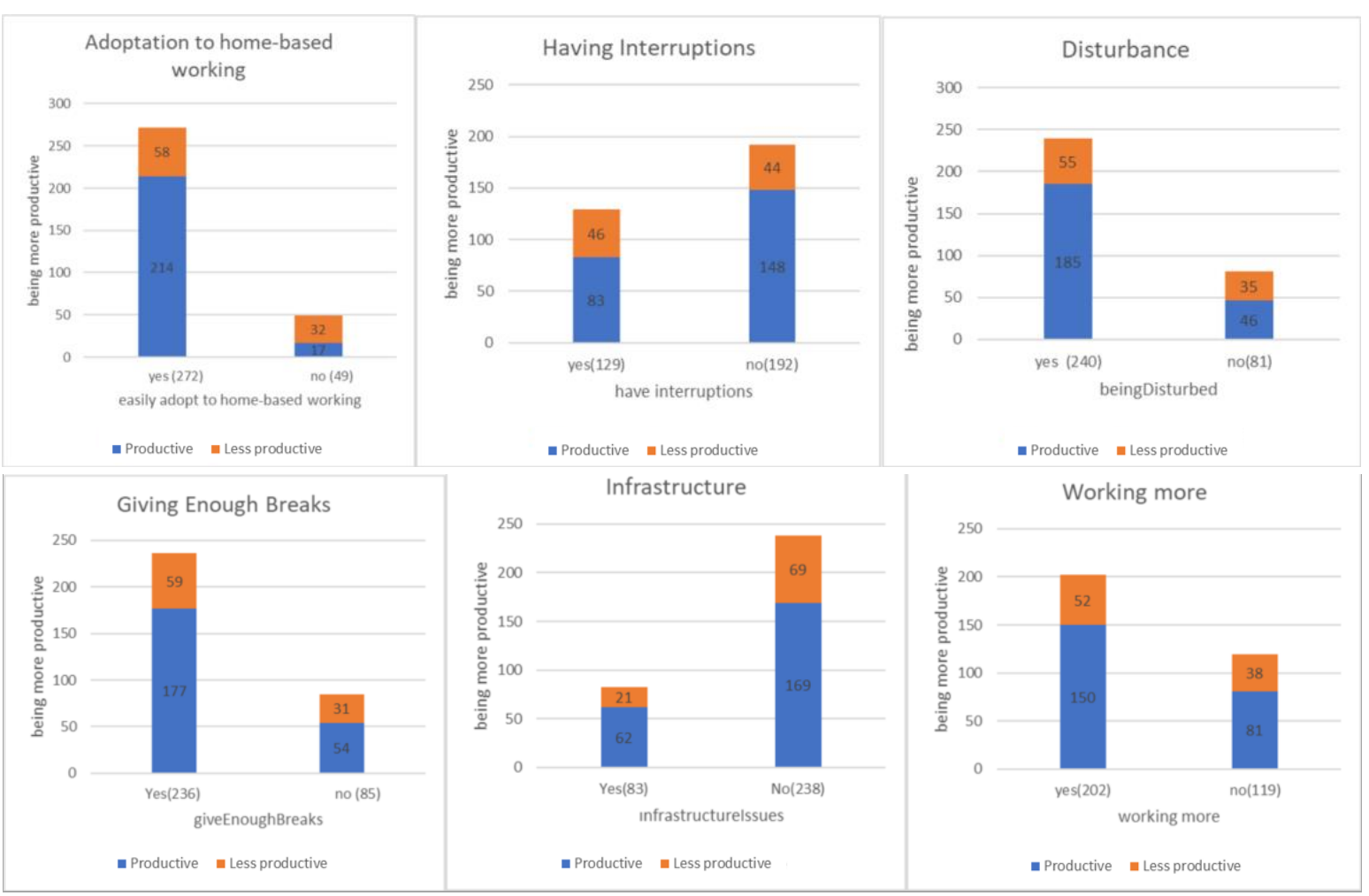

Figure 2. Examining the types of interruptions software professionals handled during their work day, mostly they were arising from kids and routine housework. 


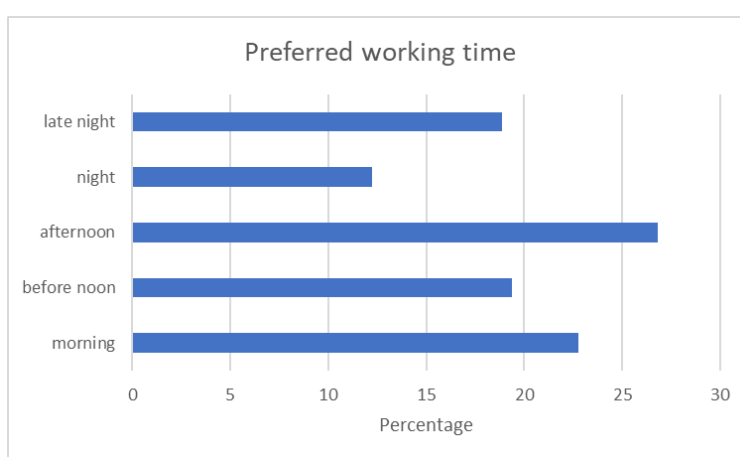

Figure 3. Preferred working time during Covid-19 homebased working.

The results of the two-way Chi-square test with two variables also revealed that, there is no significant relationship between self-reported productivity and workingMore variable.

Table 2. Correlations between independent variables and self-reported productivity.

\begin{tabular}{|c|c|c|c|c|c|}
\hline Variable (n) & $\%$ & $\begin{array}{l}\text { morePro } \\
\text { ductive }\end{array}$ & $\begin{array}{c}\text { less } \\
\text { productive }\end{array}$ & $\mathbf{p}^{*}$ & $\begin{array}{l}\text { Pearson } \\
\text { Chi } \\
\text { Square }^{\text {a }}\end{array}$ \\
\hline \multicolumn{6}{|l|}{$\begin{array}{l}\text { easyAdaptationtoHo } \\
\text { meWork }\end{array}$} \\
\hline yes (272) & 84.7 & 214 & 58 & .000 & 39.8 \\
\hline no (49) & 15.3 & 17 & 32 & & \\
\hline \multicolumn{6}{|l|}{ giveEnoughBreaks } \\
\hline yes(236) & 73.5 & 177 & 59 & .000 & 326.1 \\
\hline no (85) & 26.5 & 54 & 31 & & \\
\hline \multicolumn{6}{|c|}{ beingDisturbed } \\
\hline yes $(240)$ & 74.8 & 185 & 55 & .000 & 12.4 \\
\hline no(81) & 25.2 & 46 & 35 & & \\
\hline \multicolumn{6}{|l|}{ infrastructurelssues } \\
\hline Yes(83) & 25.9 & 62 & 21 & .000 & 322.4 \\
\hline $\mathrm{No}(238)$ & 74.1 & 169 & 69 & & \\
\hline \multicolumn{6}{|l|}{ havelnterruptions } \\
\hline yes(129) & 40.2 & 83 & 46 & 000 & 328.2 \\
\hline no(192) & 59.8 & 148 & 44 & .000 & \\
\hline \multicolumn{6}{|l|}{ workingMore } \\
\hline yes(202) & 62.9 & 150 & 52 & & 1.4 \\
\hline no(119) & 37.1 & 81 & 38 & .233 & \\
\hline
\end{tabular}

\section{Discussion and Conclusion}

Due to strict Covid-19 pandemic measures, though country wide measures showed an alteration around the world, the common case was that mostly work settings were houses for software professionals and thus home based working was considered as the only ideal setting in general. Hence this study intended to explore the software professionals' home-based working experience and their self-reported productivity during pandemic forced home-based arrangement. For this purpose, the study examined the characteristics of homebased working including; adaptation, breaks, being disturbed during the home-based working, infrastructure issues, working hours, interruptions and productivity in the working environment through an online survey conducted via social media platforms of software professionals.

Responses of software professionals show that adoption to the new work setting due to pandemic was mostly easy for software professionals, yet they still had to handle interruptions, that increased in frequency mainly as a result of working in an environment shared with all family members.

In terms of working hours, most of the software practitioners reported that they worked longer hours during this pandemic period. Two main underlying reasons appeared to be dominant for this case could be the difficulty in balancing work and life responsibilities in home-based settings and in relation, the increased amount of work load in comparison to pre-Covid usuals accordingly.

Furthermore, in terms of interruptions housework and kids were reported as the two primary ones in home based settings. It is well acknowledged that being at home with all the family members brings in extra responsibilities during work hours. Consequently, switching between work and house responsibilities may diminish the resources an individual possesses and hence may result in stress and low work performance. When individuals experience work-life imbalance, they may suffer from critical consequences such as low satisfaction (Mesmer-Magnus and Viswesvaran 2005), deteriorated health and wellbeing (Allen et al. 2000) and low performance at work (Gilboa et al. 2013), all of which naturally have impacts on productivity within every aspect of works carried out.

Additionally, focusing on productivity during work intervals, afternoons and mornings were reported as the most productive work intervals for software professionals. Working late at nights was mentioned to be less productive.

The results of the feedbacks furthermore show that productivity is correlated with software professionals' easy adaptation to home-based working, giving enough breaks, being disturbed 
during the home-based working, infrastructure issues, and having interruptions in the home-based working environment.

This study sheds light into fundamental challenges of software professionals in home based working settings. And as of practical implications, above mentioned findings represent only a small portion of issues software company management teams and/or professionals should consider in order to enhance performance and productivity.

Thus, while limitations do exist, it is believed that a deeper understanding of home-based work setting characteristics could guide software professionals for better home-based work setting experience.

\section{References}

Adamczyk, P. D., and Bailey, B. P., 2004. If not now, when? Proceedings of the 2004 Conference on Human Factors in Computing Systems - CHI '04, 271-278.

Allen, T. D., Herst, D. E., Bruck, C. S., and Sutton, M., 2000. Consequences associated with work-to-family conflict: a review and agenda for future research. In Journal of occupational health psychology, 5, 2, 278308.

Bailey, B. P., Konstan, J. A., and Carlis, J. V., 2000. Measuring the effects of interruptions on task performance in the user interface. Proceedings of the IEEE International Conference on Systems, Man and Cybernetics, 2, 757-762.

Brumby, D. P., Cox, A. L., Back, J., and Gould, S. J. J., 2013. Recovering from an interruption: Investigating speedaccuracy trade-offs in task resumption behavior. Journal of Experimental Psychology: Applied, 19(2), 95-107.

Conradie, W. J., and de Klerk, J. J., 2019. To flex or not to flex? Flexible work arrangements amongst software developers in an emerging economy. SA Journal of Human Resource Management, 17(1), 1-12.

Cutrell, E. B., Czerwinski, M., and Horvitz, E., 2000. Effects of instant messaging interruptions on computing tasks. Conference on Human Factors in Computing Systems - Proceedings, 99-100.
Czerwinski, M., Horvitz, E., and Wilhite, S., 2004. A diary study of task switching and interruptions. Conference on Human Factors in Computing Systems Proceedings, 175-182.

DeMarco, T., and Lister, T., 1985. Programmer Performance and the Effects of the Workplace. Proceedings - International Conference on Software Engineering, 268-272.

DeMarco, T., and Lister, T., 2013. Peopleware: Productive Projects and Teams, 3rd ed.. Addison-Wesley Professional.

Gilboa, S., Shirom, A., Fried, Y., and Cooper, C. L., 2013. A Meta-Analysis of Work Demand Stressors and Job Performance: Examining Main and Moderating Effects. In From Stress to Wellbeing, 1, 188-230.

Golden, T. D., and Veiga, J. F., 2008. The impact of superior-subordinate relationships on the commitment, job satisfaction, and performance of virtual workers. Leadership Quarterly, 19(1), 77-88.

Harrington, J. M., 2001. Health effects of shift work and extended hours of work. In Occupational and Environmental Medicine, 58, 1, 68-72.

Hill, E. J., Miller, B. C., Weiner, S. P., and Colihan, J., 1998. Influences of the Virtual Office on Aspects Of Work And Work/Life Balance. Personnel Psychology, 51(3), 667-683.

Iqbal, S. T., Adamczyk, P. D., Zheng, S., and Bailey, B. P., 2005. Towards an Index of Opportunity: Understanding Changes in Mental Workload during Task Execution. Proceedings of the SIGCHI Conference on Human Factors in Computing Systems - $\mathrm{CHI}$ '05.

Johnson, B., Zimmermann, T., and Bird, C., 2019. The Effect of Work Environments on Productivity and Satisfaction of Software Engineers. IEEE Transactions on Software Engineering, 1-1.

Kushlev, K., Proulx, J., and Dunn, E. W., 2016. "Silence your phones": Smartphone notifications increase inattention and hyperactivity symptoms. Conference on Human Factors in Computing Systems Proceedings, 1011-1020. 
Leaman, A., and Bordass, B., 1999. Productivity in buildings: The "killer" variables. Building Research and Information, 27(1), 4-19.

Li, S. Y. W., Blandford, A., Cairns, P., and Young, R. M., 2008. The Effect of Interruptions on Postcompletion and Other Procedural Errors: An Account Based on the Activation-Based Goal Memory Model. Journal of Experimental Psychology: Applied, 14(4), 314-328.

Mark, G., Gudith, D., and Klocke, U., 2008. The cost of interrupted work: More speed and stress. Conference on Human Factors in Computing Systems Proceedings, 107-110.

Mark, G., Iqbal, S., Czerwinski, M., and Johns, P., 2015. Focused, aroused, but so distractible: A temporal perspective on multitasking and communications. CSCW 2015 - Proceedings of the 2015 ACM International Conference on Computer-Supported Cooperative Work and Social Computing, 903-916.

Mark, G., Iqbal, S. T., Czerwinski, M., Johns, P., and Sano, A., 2016. Email duration, batching and selfinterruption: Patterns of email use on productivity and stress. Conference on Human Factors in Computing Systems - Proceedings, 1717-1728.

Mesmer-Magnus, J. R., and Viswesvaran, C., 2005. Convergence between measures of work-to-family and family-to-work conflict: A meta-analytic examination. Journal of Vocational Behavior, 67(2), 215-232.

Meyer, A., Barr, E. T., Bird, C., and Zimmermann, T., 2019. Today was a Good Day: The Daily Life of Software Developers. IEEE Transactions on Software Engineering, 47(5), 863 - 880.

Meyer, A. N., Barton, L. E., Murphy, G. C., Zimmermann, T., and Fritz, T., 2017. The Work Life of Developers: Activities, Switches and Perceived Productivity. IEEE Transactions on Software Engineering, 43(12), 11781193.

Oldham, G. R., 1988. Effects of Changes in Workspace Partitions and Spatial Density on Employee Reactions: A Quasi-Experiment. Journal of Applied Psychology, 73(2), 253-258.

Palvalin, M., 2017. How to measure impacts of work environment changes on knowledge work productivity - validation and improvement of the SmartWoW tool. Measuring Business Excellence, 21(2), 175-190.

Parnin, C., and Rugaber, S., 2011. Resumption strategies for interrupted programming tasks. Software Quality Journal, 19(1), 5-34.

Raghuram, S., and Wiesenfeld, B., 2004. Work-nonwork conflict and job stress among virtual workers. Human Resource Management, 43(2-3), 259-277.

Rodriguez, A., Tanaka, F., and Kamei, Y., 2018. Empirical study on the relationship between developer's working habits and efficiency. Proceedings International Conference on Software Engineering, 74-77.

Tsunoda, M., Monden, A., Kakimoto, T., Kamei, Y., and Matsumoto, K. I., 2006. Analyzing OSS developers' working time using mailing lists archives. Proceedings - International Conference on Software Engineering, 181-182.

Wagner, S., and Murphy-Hill, E., 2019. Factors That Influence Productivity: A Checklist. In: Sadowski C., Zimmermann T. (eds) Rethinking Productivity in Software Engineering. Apress, Berkeley, CA, 69-84.

\subsection{Internet References}

IOSH., 2014. Home office, mobile office. losh, 17. https://www.iosh.com/media/1507/iosh-homeoffice-mobile-office-full-report-2014.pdf 